ences were detected between groups $\mathrm{A}$ and $\mathrm{B}$. Three previous reports describe an association between $\mathrm{BfF} 1$ and insulin dependent diabetes $[7,8,9]$ but two others found no association $[10,11]$. The discrepancies may be due to geographical variations or to differences in the selection of patients studied [9].

The available data provide no evidence that HLA type or Bf allele are genetic markers for proliferative retinopathy,

\section{H. Cove and J. M. Walker \\ Dudley Road Hospital \\ Birmingham B18 7QH}

\section{Wells}

Department of Clinical Genetics Birmingham Maternity Hospital Birmingham B15 2TH

\section{References}

1. Larkins RG, Martin FIR, Taite BD (1978) HLA patterns and diabetic retinopathy. Br Med J I: 1111

2. Deckert T, Egeberg J, Frimoldt-Moller C, Sander E, Svejgaard A (1979) Basement membrane thickness, insulin antibodies and HLA-antigens in long standing insulin dependant diabetics with and without severe retinopathy. Diabetologia 17: $91-96$

3. Standl E, Dexel T, Lander T, Albert ED, ScholzS (1980) HLA-antigens and diabetic retinopathy: A different view warranted (Letter to the Editor). Diabetologia 18: 79-80

4. Jervell J, Solheim B (1979) HLA-antigens in long standing insulin dependent diabetics with terminal nephropathy and retinopathy with and without loss of vision (Letter to the Editor). Diabetologia 17: 391

5. Cudworth AG, Woodrow JC (1976) Genetic susceptibility in diabetes mellitus: Analysis of HLA association. Br Med $\mathrm{J}$ II: $846-848$

6. Cudworth AG, Festenstein H (1978) HLA genetic heterogeneity in diabetes mellitus. Br Med Bull 34: 285-289

7. Raum D, Stein R, Alper CA, Gabbay KH (1979) Genetic marker for insulin-dependent diabetes mellitus. Lancet $\mathrm{I}$ : $1208-1210$

8. Deschamps I, Lestradet H, Marcelli-Barge A, Benajam A, Busson M, Hors J, Dausset J (1979) Properdin factor B alleles as markers for insulin-dependent diabetes. Lancet II: 793

9. Kirk RL, Serjeantson SW, Theophilus J, Zimmet P, Whitehouse S, Court JM (1979) Age relationship between insulindependent diabetes and rare alleles of properdin factor B. Lancet II: 537

10. Bernal JE, Ellis EA, Haigh J (1979) Bf in insulin-dependent diabetes mellitus. Lancet II: 961

11. Weitkamp LR, Barbosa J, Guttormsen SA, Johnson S (1979) Insulin-dependent diabetes mellitus and properdin factor $\mathbf{B}$. Lancet II: $369-370$

12. Barbosa J, Ramsay R (1980) Genetic contribution to retinopathy (Letter to the Editor). Diabetologia 18: 515

\section{H. Cove}

Senior Medical Registrar

Dudley Road Hospital

Dudley Road

Birmingham B18 7QH

England

\title{
Rapid Fluctuations in Glycosylated Haemoglobin Concentration as Related to Acute Changes in Blood Glucose
}

Sir,

In a recent article [1] Dr. Bolli and co-workers reported that $\mathrm{HbAI}$ levels decreased significantly after only 3 days of treatment with the "artificial endocrine pancreas" (Biostator). This and other in vivo and in vitro observations [2-5] raise questions concerning the concept, based on previous clinical studies [6-8], that $\mathrm{HbA}_{\text {Ic }}$ degradation takes place slowly (on the order of weeks or months) and that $\mathrm{HbA}_{\mathrm{Ic}}$ levels therefore are clinically useful to assess long-term blood glucose control.

It is of note that the original methods of $\mathrm{HbA}_{\mathrm{Ic}}$ determination, on which this concept was based, included prolonged dialysis of the haemolysates, whereas many of the more recent modifications of this technique, including high pressure liquid chromatography, use nondialysed samples, and the microcolumn commercial methods, which include a haemolysing agent, use whole blood [9-11]. Although it is unclear whether all the clinical studies indicating rapid fluctuations in glycohaemoglobins utilized nondialysed samples for $\mathrm{HbA}_{\mathrm{Ic}}$ analysis, it would appear that most did. It is well known that an unstable, dialysable, Schiffbase form of $\mathrm{HbA}_{\mathrm{Ic}}$ may be formed as an intermediate for the stable ketoamine end-product [12]. It is therefore likely that the dialysis step is important to minimise the effect of acute changes in blood glucose on the level of glycohaemoglobin.

In order to evaluate this possibility, one of us (J.D.) determined blood glucose and $\mathrm{HbA}_{\mathrm{Ic}}$ concentrations in a group of 24 ambulatory diabetic children, fasting and 6 hours postprandially, using three methods for $\mathrm{HbAI}$ determinations: the macrocolumn method of Schnek and Schroeder, as modified by Schwartz et al. 
[13], which uses dialysed samples; a commercially available microcolumn procedure (Quik-Sep ${ }^{\circledR}$, Isolab Inc, Akron, Ohio), which uses undialysed samples [11]; and the same commerical procedure modified by using dialysed haemolysate. When the 6-hour changes were assessed, there was a significant positive correlation ( $r=$ 0.68 ) between the change in blood glucose and that of $\mathrm{HbAI}$ with the commerical microcolumn technique, using undialysed samples; however, no such relationship was present when either the macrocolumn or the microcolumn method with dialysed haemolysates was used. Indeed, the rapid fluctuations in glycohaemoglobin related to acute changes in glucose made the commerical unmodified method useless for the evaluation of long-term control in unstable juvenile diabetics without dialysis.

These observations and those of others [14] of the degree and rapidity of $\mathrm{HbAI}$ changes suggest that the glycosylation process may, to some degree, be rapid and easily reversible. However, these fluctuations may well be a reflection of recent fluxes in glucose, and dialysed haemolysates may better reflect long-term glucose control and conform more closely to the originally held concept of $\mathrm{HbA}_{\mathrm{Ic}}$ as a slowly changing index of long-term blood glucose control.

\section{References}

1. Bolli G, Cartechini MG, Compagnucci P, Santeusanio F, Massi-Benedetti M, Calabrese G, Puxeddu A, Brunetti P (1980) Modification of glycosylated haemoglobin concentration during artificial endocrine pancreas treatment of diabetes. Evidence for a short-term effect on $\mathrm{HbA}_{\mathrm{I}(\mathrm{a}+\mathrm{b}+\mathrm{c})}$ levels. Diabetologia 18: $125-130$

2. Dunn PJ, Cole RA, Soeldner JS, Gleason RE, Kwa E, Firoozabadi H, Younger D, Graham CA (1979) Temporal relationship of glycosylated haemoglobin concentrations to glucose control in diabetics. Diabetologia 17: 213-220

3. Karamanos B, Christacopoulos P, Zachariou N, Korkolis S (1977) Rapid changes of the haemoglobin $A_{\mathrm{Ic}}\left(\mathrm{HbA}_{\mathrm{Ic}}\right)$ fraction following alterations of diabetic control. Diabetologia 13: 406

4. Svendsen PA, Christiansen JS, Welinder B, Nerup J (1979) Fast glycosylation of haemoglobin. Lancet I: 603

5. Stevens VJ, Vlassara H, Abati A, Cerami A (1977) Nonenzymatic glycosylation of hemoglobin. J Biol Chem 252: 2998-3002
6. Bunn HF, Haney DN, Kamin S, Gabbay KH, Gallop PM (1976) The biosynthesis of human hemoglobin $A_{\text {Ic. }}$ Slow glycosylation of hemoglobin in vivo. J Clin Invest 57: 1652-1659

7. Peterson CM, Jones RL (1977) Minor hemoglobins, diabetic "control", and diseases of postsynthetic protein modification. Ann Intern Med 87: 489-491

8. Ditzel J, Kjargaard JJ (1978) Haemoglobin $A_{\text {Ic }}$ concentrations after initial insulin treatment for newly discovered diabetes. $\mathrm{Br}$ Med J I: 741-742

9. Cole RA, Soeldner JS, Dunn PJ, Bunn HF (1978) A rapid method for the determination of glycosylated hemoglobins using high pressure liquid chromatography. Metabolism 27: 289-301

10. Kynoch PAM, Lehmann H (1977) Rapid estimation $(2-1 / 2$ hours) of glycosylated haemoglobin for routine purposes. Lancet II: 16

11. Abraham EC, Huff TA, Cope ND, Wilson JB Jr, Bransome ED Jr, Huisman THJ (1978) Determination of the glycosylated hemoglobins $\left(\mathrm{HbA}_{\mathrm{I}}\right)$ with a new microcolumn procedure. Suitability of the technique for assessing the clinical management of diabetes mellitus. Diabetes 27: 931-937

12. Bunn HF, Haney DN, Gabbay KH, Gallop PM (1975) Further identification of the nature and linkage of the carbohydrate in hemoglobin $\mathrm{A}_{\mathrm{Ic}}$. Biochem Biophys Res Commun 67: 103-109

13. Schwartz HC, King KC, Schwartz AL, Edmunds D, Schwartz R (1976) Effects of pregnancy on hemoglobin $A_{I c}$ in normal, gestational diabetic, and diabetic women. Diabetes 25: $1118-1122$

14. Widness JA, Rogler-Brown TL, McCormick KL, Petzold KS, Susa JB, Schwartz HC, Schwartz R (1980) Rapid fluctuations in glycohemoglobin (hemoglobin $\mathrm{A}_{\mathrm{Ic}}$ ) related to acute changes in glucose. J Lab Clin Med 95: 386-394

J. Ditzel

Department of Medicine

Aalborg Regional Hospital

DK-Aalborg, Denmark

\section{P. H. Forsham}

M. Lorenzi

Metabolic Research Unit and

Department of Medicine

University of California

San Francisco, CA, USA

\section{Fetal Hypoinsulinism as a Cause of Small Infants of Smoking Mothers?}

Sir,

The decrease in the mean birth weight of the infants of smoking mothers, as compared with those of normal non-smokers [1], may result from the relative hypoxia caused by carbon monoxide [2]. Nicotine [3] and other chemicals in tobacco smoke also may affect the birth weight reduction in these infants. The Ontario Perinatal Mortality Study [4] concluded that the reduction of birth weight in the offspring of smoking mothers is not due to a decrease in maternal nutrition as reflected in weight gain during pregnancy. However more subtle metabolic disturbances induced by smoking 